
HUMICOS NA MIGRAÇÃO DO MERCÚRIO

\title{
MERCURY AND METHYLMERCURY IN SURFACE WATERS OF ARID AND HUMID REGIONS, AND THE ROLE OF HUMIC ACIDS IN MERCURY MIGRATION
}

\section{СОДЕРЖАНИЕ РТУТИ И МЕТИЛРТУТИ В ПОВЕРХНОСТНЫХ ВОДАХ ЗАСУШЛИВЫХ И ВЛАЖНЫХ РЕГИОНОВ, И РОЛЬ ГУМИНОВЫХ КИСЛОТ В МИГРАЦИИ РТУТИ}

\author{
Safonov V.A. ${ }^{*}$, Danilova V.N. ${ }^{1}$, Ermakov V.V. ${ }^{1}$, Vorobyov V.I. ${ }^{2}$ \\ ${ }^{1}$ Vernadsky V.I. Institute of geochemistry and analytical chemistry of the Russian \\ Academy of Sciences, Moscow, Russia \\ ${ }^{2}$ Astrakhan State University, Russia \\ ${ }^{*}$ Corresponding author \\ sakhsakh@yandex.ru
}

Received 03 November 2018; received in revised form 05 January 2019; accepted 06 January 2019

\section{RESUMO}

Utilizando os métodos de extração seletiva, absorção atômica e cromatografia gás-líquido, determinamos que as águas fluviais e lacustres em regiões áridas e / ou úmidas diferem em seus índices de conteúdo total e alquilado de mercúrio. Níveis elevados de mercúrio em águas de paisagens áridas (por exemplo, no Quirguistão) não ativam o processo de metilação do metal. São discutidas as características da interação de compostos de mercúrio e húmicos como os ácidos fúlvico $(\mathrm{AF})$ e húmico $(\mathrm{AH})$. Verifica-se que os AF promovem a dispersão de mercúrio na biosfera devido à formação de complexos fúlvicos e à metilação abiogênica do mercúrio, resultando em compostos organomercúricos tóxicos. Os $\mathrm{AH}$ manifestam altos níveis de capacidade de sorção em relação aos íons de mercúrio e servem como sorventes. Em uma interação competitiva no sistema $\mathrm{AH}-\mathrm{Hg}-\mathrm{AH}$, Kd para o mercúrio diminui bruscamente com um aumento na concentração de $\mathrm{AF}$ e no sistema $\mathrm{pH}$. O metabolismo do mercúrio na biosfera em termos de seu conteúdo no complexo soloplanta é discutido.

Palavras-chave: ácido húmico, ácido fúlvico, mercúrio

\begin{abstract}
Using the methods of selective extraction, atomic absorption, and gas-liquid chromatography, we determined that the river and lake waters in arid and/or humid regions differ in their total and alkylated mercury content indices. Mercury high content levels in waters of arid landscapes (e.g., in Kyrgyzstan) do not activate metal methylation process. The features of the interaction of mercury and humic compounds like fulvic (FA) and humic (HA) acids are discussed. The FA are found to promote mercury dispersion in the biosphere due to the formation of fulvic complexes and abiogenic methylation of mercury resulting in the toxic organomercuric compounds. The HA manifest high sorption capacity levels in relation to mercury ions and serve as sorbents. At a competitive interaction in the system FA-Hg-HA, Kd for mercury drops sharply with an increase in FA concentration and $\mathrm{pH}$ system. The metabolism of mercury in the biosphere in terms of its content in the soilplant complex is discussed.
\end{abstract}

Keywords: humic acid, fulvic acid, mercury 


\begin{abstract}
АННОТАЦИЯ
Используя методы селективной экстракции, атомной абсорбции и газожидкостной хроматографии, мы определили, что речные и озерные воды в засушливых и/или влажных районах различаются по их общему и алкилированному показателю содержания ртути. Высокий уровень содержания ртути в водах засушливых ландшафтов (например, в Кыргызстане) не активирует процесс метилирования металлов. Обсуждаются особенности взаимодействия ртути и гуминовых соединений, таких как фульвиновая (FA) и гуминовая (HA) кислоты. Было обнаружено, что FА способствует ртутной дисперсии в биосфере из-за образования фульвовых комплексов и абиогенного метилирования ртути, приводящего к токсическим органокурьерным соединениям. НА проявляют высокие уровни сорбционной емкости по отношению к ионам ртути и служат сорбентами. При конкурентном взаимодействии в системе $\mathrm{FA}-\mathrm{Hg}-\mathrm{HA}$, Кд для ртути резко падает с увеличением концентрации FA и системы рН. Обсуждается метаболизм ртути в биосфере с точки зрения ее содержания в почвенно-растительном комплексе.
\end{abstract}

Ключевые слова: гуминовая кислота, фульвовая кислота, ртуть

\section{INTRODUCTION}

Mercury is one of the most toxic trace element and included in the list of priority pollutants [4, 19]. Possessing some specific physical and chemical features, mercury is a good migrant in the environment, depending on the current conditions accumulating and redistributing in the components of water and surface ecosystems, gas and water environments $[3,8]$. Among the wide range of various interactions running in natural environments, the following processes are outlined as principal for the solution phase: a) hydrolysis of mercury (II) ions and their complex formation to FA [10], and b) abiogenic and biogenic methylation of mercury [4-7].

\section{MATERIALS AND METHODS}

The sampling areas with high levels of mercury, situated in the South-Western part of Osh region of the Kyrgyz Republic: mines Khaidarken and Chauvay (Hg-As-Sb), Kadamzhay mine (Sb-As-Hg) [8]. The background regions were Krasnodar reservoir, Northern Dvina river near Arkhangelsk and others (Russia). Within these territories were selected the water samples, different organisms (aquatic and terrestrial plants, insects, fishes, frogs, lizards organs and tissues of sheep), sediments, and soil.

Mercury interaction with FA was studied by a method of solubility in microvariant. The molecular mass distribution of mercury (II) fulvic complexes was studied by filtration through a Sephadex G-25 column [20]. The experiments for mercury sorption on $\mathrm{HA}$ and the interactions in a three-component system were conducted in cylindrical Teflon vessels with screw-on lids. The mercury content levels in the solutions were determined using a method of cold vapor with atomic-fluorescent registration of the analytical signal, and AES-ICP method [2, 5, 16]. FA concentrations were determined using a spectrophotometric method from solution absorbancy indices at $\lambda=420 \mathrm{~nm}$. The methylmercury concentrations were determined using gas-liquid chromatography with an electronic capture detector following an extraction concentrating with benzol (toluene) from acid solutions in the cold $[5,10]$.

\section{RESULTS}

In the course of the surveillance of various areas with different mercury levels in the environment (the Northern Dvina, Moscow suburbs, Kuban, and South Kyrgyzstan) some data array has been obtained on mercury and alkylmercury in various natural objects including natural surface waters. Methylmercury was found to exist in water ecosystems and water organisms only. Neither methyl- (MMC) nor ethylmercury chloride was found in the soils, soil microorganisms biomass or plants with the method sensitivity level of 0.5 to $1.0 \mathrm{ng} / \mathrm{g}[6,7]$.

The water analyses revealed the following:

- methylmercury concentrations in surface waters vary ranging from $<2$ to $80 \mathrm{ng} / \mathrm{l}$, making 4 to $50 \%$ of their total content at a solution (filtrate) phase;

- at a sharp increase in total mercury concentrations in natural waters, methylmercury levels rise slowly while methylated mercury percentage drops (see Fig. 1); 
- a tendency of a positive correlation between methylmercury content levels in the waters and the bottom deposits (i.e., soil or silt) is noted;

- along with the higher coefficients of mercury biological absorption by organisms in arid regions as compared to the humid ones, a tendency of still more intensive mercury alkylation in a water environment is observed. However, in the conditions of hot climate methylmercury can migrate from reservoirs to the atmosphere and decompose being affected by solar radiation.

Among the aspects of abiogenic methylation, reactions with the implication of humic substances are of substantial significance.

The humic substances (HS) are complex mixtures of high molecular organic compounds of natural origin formed through the plant and/or animal organic residues decomposition. They represent a macro component of the organic matter of both the soil and the water ecosystems. $\mathrm{HS}$ are subdivided into three constituents, namely humin, which is an inextractable residue, humic acids (HA) and fulvic acids (FA).

To estimate the role of fulvic acids in organomercuric compounds formation, the influence of time period of mercury (II) exposure to FA solution(s) upon mercury alkylation process has been investigated on a model system (see Fig. 2). As follows from the figure, the methylation process, having reached a certain level, is replaced or hampered by a reverse process of dealkylation.

Nevertheless, it should be noted that the interaction of mercury (II) with FA in natural environments results not only in appearing some rather toxic organomercuric compounds formed through abiogenic methylation, but also in drastic growth of mercury migratory capacity as seen both in waters and soils due to formation of stable \& soluble mercury (II) fulvic compounds [11, 21].

We chose elemental mercury, and mercuric sulfide as the original mercury (II) compounds in the fulvic acid - Me model system.

Elemental mercury is a major form of mercury existence in the atmosphere; when reaching the earth surface together with atmospheric precipitates, it interacts with soil and/or water-organic substances.

Also, investigations into model systems using mercuric sulfide as the element basic mineral form as seen in the Earth's crust were of some interest for the understanding of mercury migration mechanism in the biosphere.

The dependence of elemental mercury and mercuric sulfide solubility on fulvic acid concentrations was investigated at various $\mathrm{pH}$ values of 5.0, 6.0 and 7.0.

Together with the growth of FA concentrations in the systems under investigation, mercury concentrations also increased notably (Fig. 3), which is due to the complex formation processes. The data for the solubility method allows identification of the mercury fulvic complexes composition and stability indices. The $\mathrm{Hg}$ :FA correlation in the complex compounds was graphically established as a slope ratio of the lines. The obtained $\operatorname{tg} \alpha$ values point to the prevalence of fulvic complexes with $\mathrm{Hg}: \mathrm{FA}$ composition $=1: 1$ in equilibrium solution for $F A$ associated with the average molecular weight $\mathrm{Mw}$ $=2200$ characteristic for $\mathrm{pH}=5.0$.

The results of the calculations for conditional constants of the mercury (II) fulvic complexes stability as obtained in the course of analyzing the HgO-FA and HgS-FA systems are summarized in Table. 1.

We determined that highly durable \& soluble complex compounds are formed in the fulvic systems containing elemental mercury and mercuric sulfide. The values of conditional stability constants for mercury (II) fulvic complexes linearly depend on $\mathrm{pH}$, which is conditioned by some FA specific features, namely by their tendency to make reversible associations and a possibility of structural rearrangements within $\mathrm{FA}$ molecules due to $\mathrm{pH}$ rates growth.

The molecular mass distribution of the mercury (II) fulvic complexes was studied using a gel filtration method. The experimental data suggest that more than $70 \%$ of mercury is evaluated in fractions with the output volumes characteristic of substances with molecular weights ranging from 600 to $5000 \mathrm{Da}$.

Thus, the model system Hg-FA the high molecular mercury complexes with associated FA forms drastically prevail in the solutions, which promotes metal migration within environmental objects.

Being somewhat higher molecular and slightly soluble, the humic acids in natural objects behave as complex-forming sorbents, promoting metal concentration in soils, water suspensions, and bottom deposits. Using the Hg-humic acid 
model system, characteristics of ash-free HA preparations as extracted from turf, marine sediments, and sapropel, as well as the mechanism of their interactions with mercury ions, were studied. The HA sorption capacity indices with relation to mercury ions are high enough reaching 300 to $340 \mathrm{mg} / \mathrm{g}$ for HA extracted from turf and sapropel, and $175 \mathrm{mg} / \mathrm{g}$ for the HA found in marine sediments (see Fig. 4).

From the sorption isotherms, the conditional constants of mercury affinity to HA sorption centers were calculated using a method of quantitative physical \& chemical analysis, their logarithm values ranging within 4.1 to 4.95 .

Thus, HA serves as an effective natural geochemical barrier concentrating mercury.

The actual mercury mobility in the biosphere is controlled by the competition of metal-FA versus HA complex formation processes (Fig. 5). With the growth of FA concentrations, mercury distribution $(\mathrm{Kd})$ in the $\mathrm{FA}-\mathrm{Hg}(\mathrm{II})-\mathrm{HA}$ model system drops noticeably.

At the competitive interactions in the systems mercury fulvate-HA and $\mathrm{Hg}$ (II)-FA-HA (see Table 1), mercury distribution coefficient drops by one or two orders: a) with the increase in FA concentrations (at a constant $\mathrm{pH}$ value), б) with the pH growth from 2 to 6 (at a constant FA concentration).

Consequently, with the growth of $\mathrm{pH}$ values and watercolor indices due to the competitive mercury-FA or -HA complex forming, mercury dispersion over natural landscapes pronouncedly grows up, while at low $\mathrm{pH}$ levels and weak watercolor the mercury sorption on HA dominates, i.e., there is a process of mercury accumulation in environmental objects.

\section{Transformation of mercury}

The anomalies with the high content of mercury in the environment and organisms are a striking example of azonal natural-technogenic and technogenic biogeochemical (BGC) provinces, for example, Haidarken, Kadamzhay, Chauvay, of a primary and secondary genesis [8]. BGC provinces are characterized by abnormal high concentration of mercury, antimony, and arsenic in BGC food chains and manifestation of the pronounced biological reactions of organisms (accumulation of elements, the transformation of mercury, morphological changes in plants, toxicoses of man and animals). The chronic mercury toxicosis of sheep is characterized by a decrease of a hemoglobin level, catalase and glutathione peroxidase activities, blocking of thiol groups, violation of synthesis of thyrotrophic hormones, calcium-phosphoric metabolism. The increase of the content of mercury in the environment and bodies of animals is accompanied by a sharp activation of synthesis of metallothionein, decreasing during mercury detoxication by sodium thiosulfate $[8,9]$.

Under the high content of mercury in soils (about $240 \mathrm{mg} / \mathrm{kg}$ ), landscape plants (about 184 $\mathrm{mg} / \mathrm{kg}$ ), biomass of microorganisms (about 160 $\mathrm{mg} / \mathrm{kg}$ ), organs and tissues of animals (about 10 $\mathrm{mg} / \mathrm{kg}$ ) from BGC mercury provinces of alkyl mercury compounds practically are not revealed in this objects. The methylmercury presents mainly in water, ground sediments, water organisms, some insects (for example, larvae and pupae of mosquitoes), amphibian and reptiles. The methylation form of mercury (from the common concentration of metal) accounts about 46, 28 and $18 \%$ in fishes, frogs, and lizards respectively. About $20 \%$ of mercury in methylation form migrates in natural waters, especially during the maximal biological activity of reservoirs. The content of alkyl mercury in water tanks of mercury provinces is higher only in 1,52 times than the level of methylmercury in natural waters of a European part of Russia [4].

The experimental data specifies the prevalence of transformation of mercury into methylmercury in a water medium. Its dealkylation, interaction with thio- and disulfide groups of proteins, peptides and amino acids with the subsequent neutralization in sulfide form takes place in overland organisms. Probably the mercury methylation is a reflection of alkylation, dominant in the condition of a primary atmosphere and hydrosphere of the Earth, which has the reductive character. As a whole, the subsequent evolution of organisms and the biosphere has resulted in the loss of this mechanism, especially during the increased mercury inhalation from bowels of the Earth. In this condition, the bigger part of organisms becomes capable of desalkylate methylmercury synthesized in the biosphere by biogenic and abiogenic ways. We determine precisely this process in overland organisms $[3,4,13]$.

The process of methylation $\mathrm{Hg}(\mathrm{II})$ in water medium depends on the temperature, $\mathrm{pH}$, Eh, the concentration of an element, type of water, the content of organic matters and total microbiological activity of medium. It seems that 
the methylation, reaching a certain level, is changed and braked by the reverse process of dealkylation. The methylation takes place on suspended sediment of organic matters in water and in the top part of deposits.

Among the aspects of abiogenic methylation, except transformation by methylsilanes, two types of reactions, with the participation of methylcobalamin and substances of humic origin, have essential importance [18]. The organisms, capable of synthesis of $\mathrm{CH} 4$ from carbon dioxide and hydrogen, proved to be active concerning the mercury methylation. The enzymatic and unfermentative mercury methylation with the participation of three basic co-enzymes-S-adenosylmethionine, derivatives of $5, \mathrm{~N}$ - methyltetrahydrofolate and derivatives of vitamin B12 - cobalt (III) methylcorrinoides is possible in organisms. In the latter case, the carb-anion ( $\mathrm{CH} 3-)$ directly reacts with $\mathrm{Hg} 2+$. The speed of reaction depends from E10 (Fig. 6). If oxidation-reduction potential of an ion of metal is more than $+805 \mathrm{mv}$, it methylates by carb-anion (for example, selenium, mercury, tellurium, lead), else, during the transport of radical (tin, arsenic, chromium). However, alkyls of lead, cadmium, and zinc are unstable in water solutions. There is also the formation of dimethylmercury during the process of transmethylation: $\mathrm{CH} 3-\mathrm{Hg}-\mathrm{CH} 3$.

$\mathrm{CH} 3-\mathrm{Hg}+\rightarrow$ donor of a methyl group $\rightarrow$

It is necessary to pay attention to the scheme of BGC transformation of mercury in the biosphere (Fig. 6).

The water and land ecosystems are precisely separated on it. The elementary and ion forms of mercury (II) are methylating to methylmercury-ion and dimethylmercury under the influence of anaerobic and aerobic microorganisms and organic matters - donors of a carbonic ion or radical $[14,15]$. The latter, not keeping in a water medium, acts to the atmosphere, being decomposed to elementary mercury [23].

The $\mathrm{HgO}$, which once again acts to hydrosphere with sediments again. The salts of methylmercury are accumulated by water organisms, in particular by water and bottom inhabitants. The methylmercury in the form of metal is liberated from detritus of dead organisms by bacteria [12, 17]. The formation of dimethylmercury arises with the redundancy of a carbonic ion, inorganic nitrogen and high volume of $\mathrm{pH}$, and oxidation of elementary mercury to the ion (II) - in the presence of oxygen and organic matter. Partially elementary mercury is eliminated to the atmosphere by water plants [1, 22]. For want of it, the function of humic acids can consist not only in the delivery of methyl-groups but also in the reservation of the inorganic forms $\mathrm{Hg}$ (II).

The processes of dealkylation of methylmercury and its combination with metallothionines prevail in the land animals. Apparently, the bacterial regulation of mercury conversion plays a vital part. It is regulated by the appropriate genes and depends on the concentration of mercury in the medium of organisms. Moreover, the exhalation of elementary mercury by organisms is also bound up with resistance genes (plasmid DNA), which are being formed in bacteria only in extremal conditions [12]. However, these processes are investigated insufficiently.

\section{CONCLUSIONS:}

There are the peculiarities of the interaction of mercury with humus substances fulvo- (FA) and humic acids (HA). It was shown that $F A$ promotes to mercury dispersion in the biosphere in the result of the formation of fulvic complex and abiogenic methylation of mercury with producing toxic $\mathrm{Hg}$-organic compounds. HA, in contrast, has higher sorption volume as to mercury ions and implements the role of sorbents. $\mathrm{Kd}$ of mercury in system $\mathrm{FA}-\mathrm{Hg}-\mathrm{HA}$ is falling significantly at competition interaction with increasing concentration of $\mathrm{FA}$ and $\mathrm{pH}$ of the system. Thus, the humic acid is a regulator of mercury migration in the biosphere. Nevertheless, there is a need to evaluate the competitive interaction of different metals with the active points of humic acid in the presence of mercury and to determine the effect of temperature and solar irradiation on the state of the methylmercury in the laboratory and natural conditions.

\section{REFERENCES:}

1. Cosio C., Flück R., Regier N., Slaveykova V.I. Effects of macrophytes on the fate of mercury in aquatic systems. Environ. Toxicol. Chem., 2014. Vol. 33. P. 12251237.

2. Danilova V.N., Khushvakhtova S.D., Ermakov V.V. Interaction of mercury with humic acids // Modern problems of soil 
pollution. M.: MGU, 2010. P. 201-204 (in Russian).

3. Domagalski J. Mercury and methylmercury in water and sediment of the Sacramento River Basin, California// Applied Geochemistry, 2001. Vol. 16. P. 1677-1691.

4. Ermakov V.V. Problems of extremal geochemical ecology and biogeochemical study of the biosphere// Biogeochemistry and Geochemical Ecology. M.: Publ. GUN NPC TMG MZ RF, 2001. P. 98-144.

5. Ermakov V. V. Atomic-absorption method for the determination of mercury in tissues of animals, meat and other foods of animal origin// Methods of veterinary clinical laboratory diagnostics. M.: Kolos, 2004. P. 429-431 (in Russian).

6. Ermakov V.V. Biogenic migration and detoxication of mercury// Mercury in the biosphere. Moscow: Vernadsky Institute, 2010. P. 5-14 (in Russian).

7. Ermakov V.V., Danilova V.N. Bioaccumulation and desintoxication of mercury// Problems of Biogeochemistry and Geochemical Ecology, 2011. No.1 (15). P. 3-16 (in Russian).

8. Ermakov V.V., Letunova S.V., Konova N.I., Alekseeva S.A., Sudnitsina I.G. Geochemical ecology of organisms under conditions of mercury subregion of the biosphere// Proceedings of Biogeochem.Lab., 22. M.: Nauka, 1991. P. 24-68 (in Russian).

9. Ermakov V.V., Usenko S.I. Effect of thiosulphate on metal-accumulation in animal tissues// Proceedings of 3rd Int. Symposium on Trace Elements in Human: New Perspectives. Anhens, Greece, 2001. P. 964-973.

10. Gilmour C.C., Bell T., Bullock A., Graham A., Maizel A., Reidel G., and A.D. Kopec. Distribution and biogeochemical controls on net methyl mercury production in Penobscot River marshes and sediments 2009-2012. Edgewater: Smithsonian Environmental Research Center, 2013. 130 ps.

11. Haitzer M., Aiken G.R., Ryan J.N. Binding of mercury (II) to aquatic humic substances: influence of $\mathrm{pH}$ and source of humic substances// Environ. Sci. Technol., 2003. Vol. 37. P. 2436-2441.

12. Khesin R.B., Karasyova E.V. Mercuryresistant plasmids in bacteria from a mercury and antimony deposit area// Mol. and Gen. Genet., 1984. Vol. 197. P. 280285.

13. Koshle A., Pervez Y,F., Tiwari R.P., Pervez S. Environmental pathway and distribution pattern of total mercury among soil and groundwater matrices around an integrated steel plant in Idia// J. of Scientific and Industrial Res., 2008. Vol. 67. P. 523-530.

14. Liu Y.R., Zheng Y.M., Zhang L.M., He J.Z. Linkage between community diversity of sulfate-reducing microorganisms and methylmercury concentration in paddy soil. Environ. Sci. Pollut. Res. Int., 2014 Vol. 21. P. 1339-1348.

15. Meyer J., Schmidt A., Michalke K., Hensel $R$. Volatilisation of metals and metalloids by the microbial population of an alluvial soil// Syst. Appl. Microbiol., 2007. Vol. 30. P. 229-238.

16. Morita M., Yoshinaga J., Edmondst J.S. The determination of mercury species in environmental and biological samples// Pure \& Appl. Chem., 1998. VI. 70. No. 8. P. 1585-5.

17. Pongratz R., Heumann K.G. Production of methylated mercury, lead, and cadmium by marine bacteria as a significant natural source for atmospheric heavy metals in polar regions// Chemosphere, 1999. Vol. 39. No. 1. P. 89-102.

18. Rogers R.D. Abiological methylation of mercury in soil// J. Environ. Qual. 1977. Vol. 6. P. 463-467.

19. Scheuhammer A.M., Meyer M.W., Sandheinrich M.B., Murray M.W. Effect of environmental methylmercury on the health of wild birds, mammals, and fish// Ambio, 2007. Vol. 36. No. 1. P. 12-18.

20. Varshall G., Buachidze N. Study coexisting forms of mercury (II) in surface waters. Zh. Anal. Chemistry, 1983. Vol. 38. P. 2155-2167 (in Russian).

21. Woggon H., Klein S., Jehle D., Zydek G. Transformation reactions of special metals in organisms and in the environment. 2. Abiotic methylation reactions of mercury, especially by methyltin compounds and humic and fulvic acids// Nahrung, 1984. Vol. 28. P. 851-862 (in German).

22. Zepp R.G., Baughman G.L., Wolfe N.L., Cline D.M. Methylmercuric complexes in aquatic systems. Environ. Lett., 1974. Vol. 6. P. 117-127.

23. Zhang M.Q., Zhu Y.C., Deng R.W. 
Evaluation of mercury emission to the atmosphere from coal combustion, China // Ambio, 2002. Vol. 31. P. 482-484. 


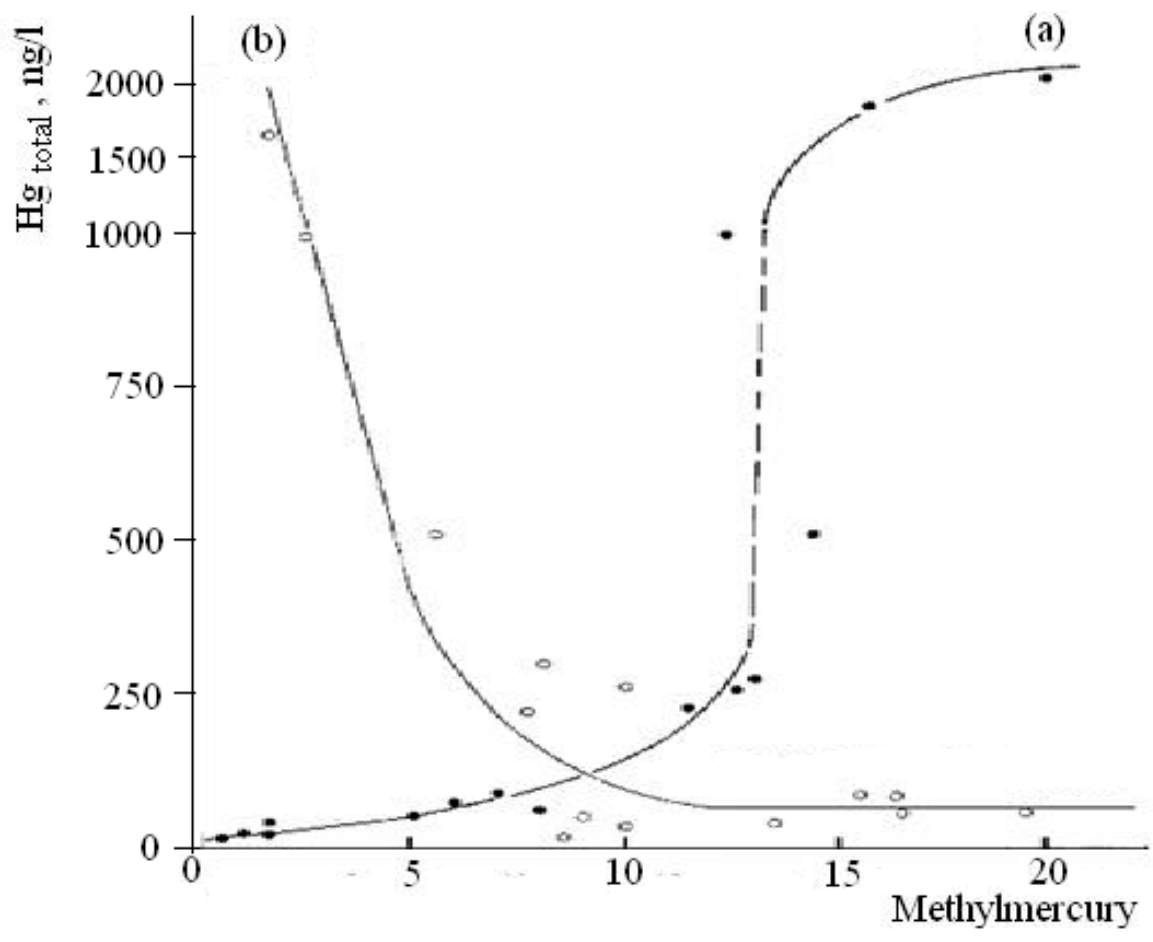

Fig. 1. Dependence of methylmercury concentrations in waters: $\mathrm{ng} / \mathrm{l}$ (a) or percent from $\mathrm{Hg}_{\text {total }}$ (b) on total mercury content indices (for the Osh and the Arkhangelsk biospheric subregions).

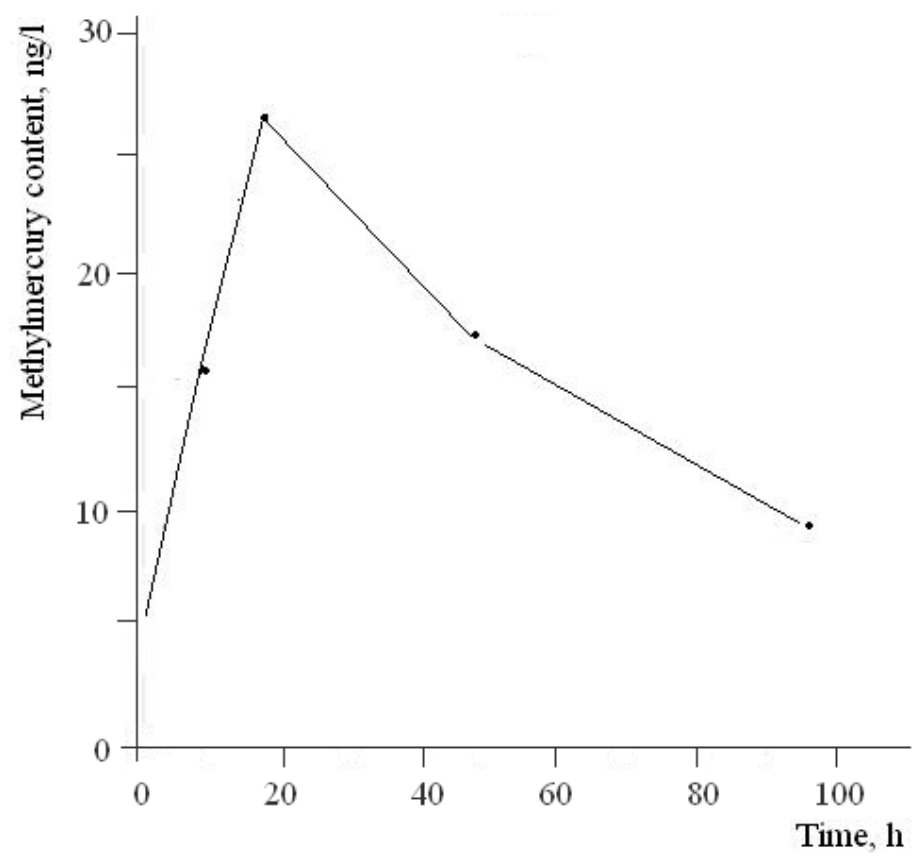

Fig. 2. The contents of methylmercur chloride (MMC) in solution depending on time of incubation (pH-6.4). 

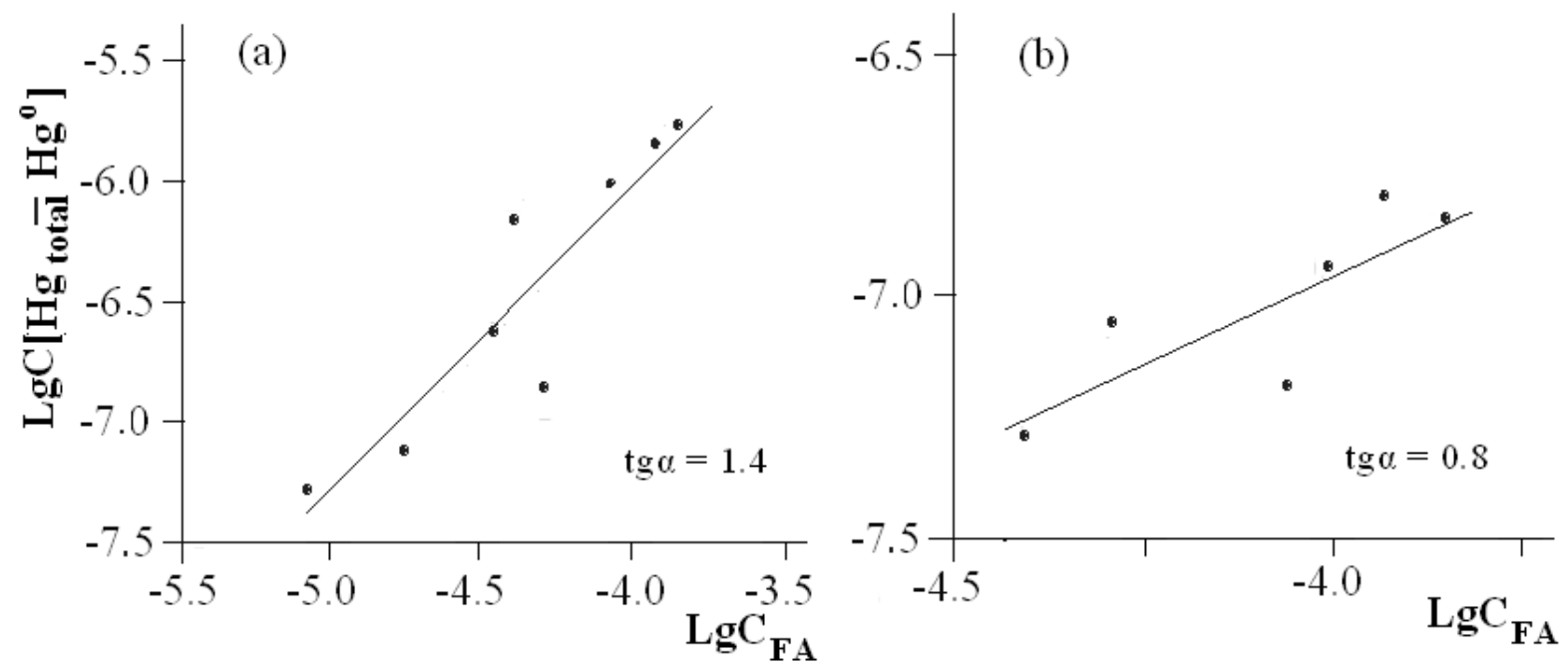

Fig. 3. Dependence of elemental mercury and cinnabar solubility indices on FA concentrations $(\mathrm{pH}=5.0)$. (a) system $\mathrm{Hg}^{\circ}-\mathrm{FA}$, (b) system $\mathrm{HgS}-\mathrm{FA}$.

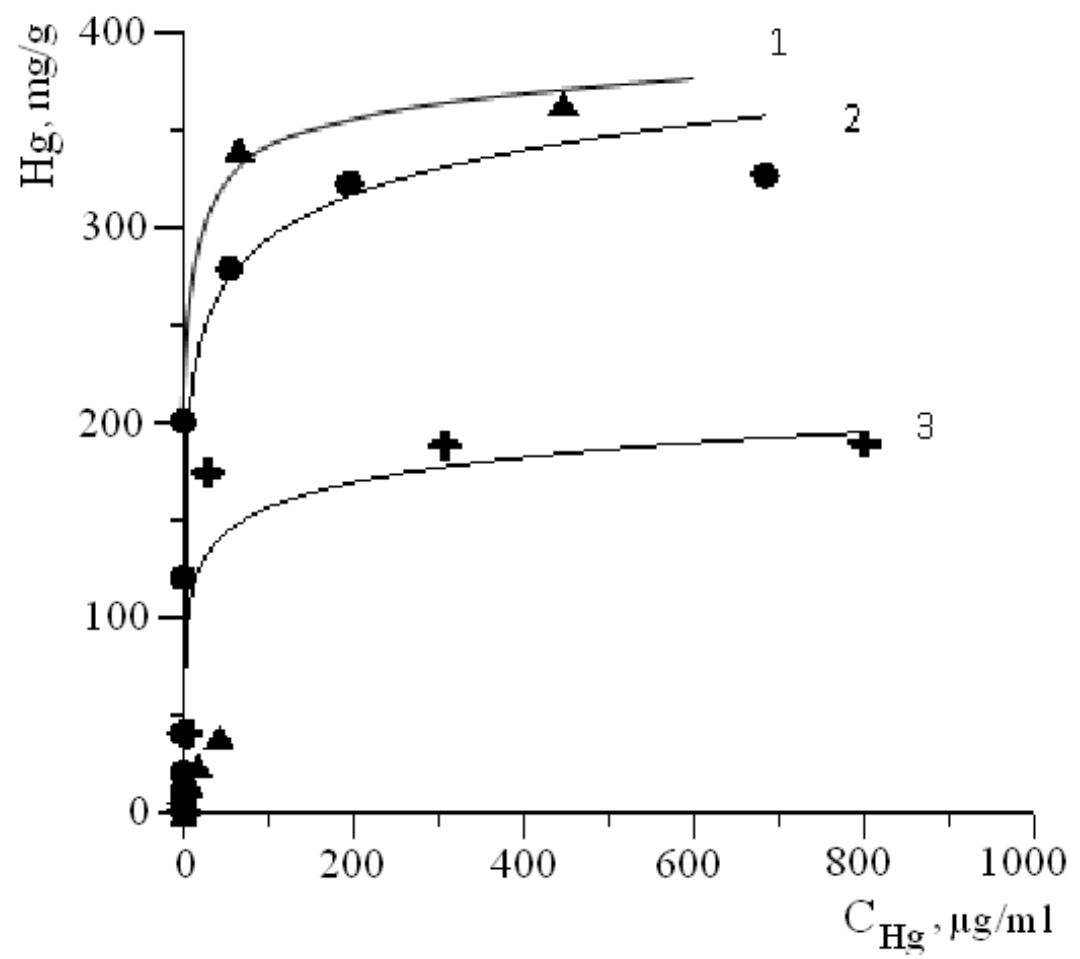

Fig. 4. Mercury sorption isotherms for HA extracted from sapropel (curve 1), turf (curve 2) and marine sediments (curve 3 ). 


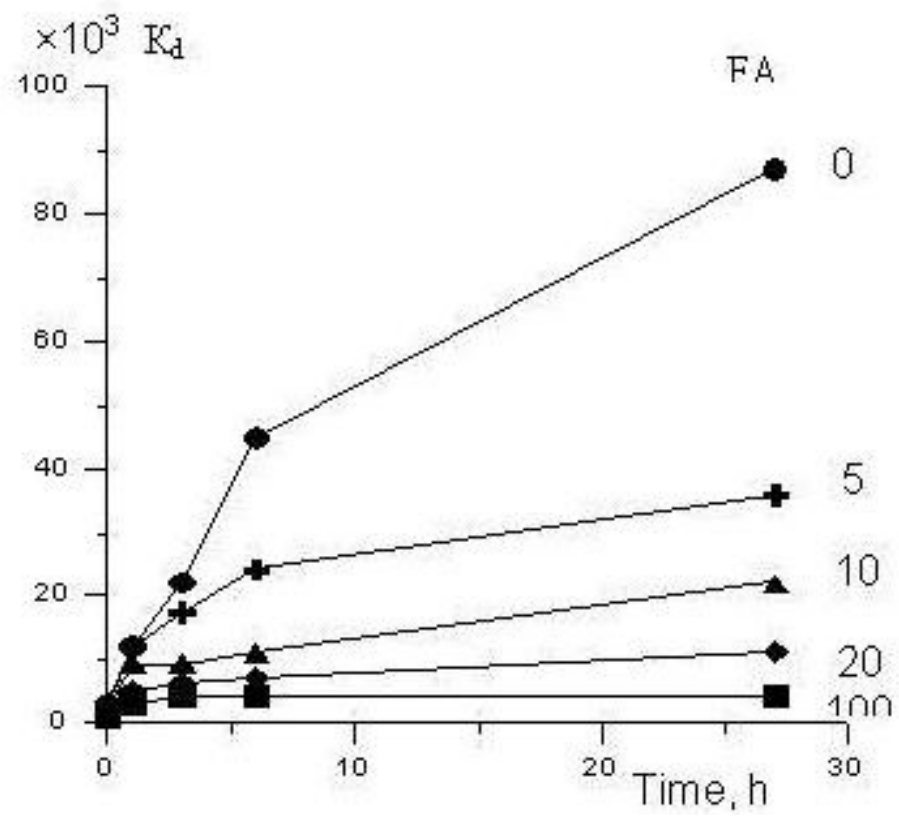

Fig. 5. Dependence of mercury $K_{d}$ values on time at various FA concentrations in solutions.

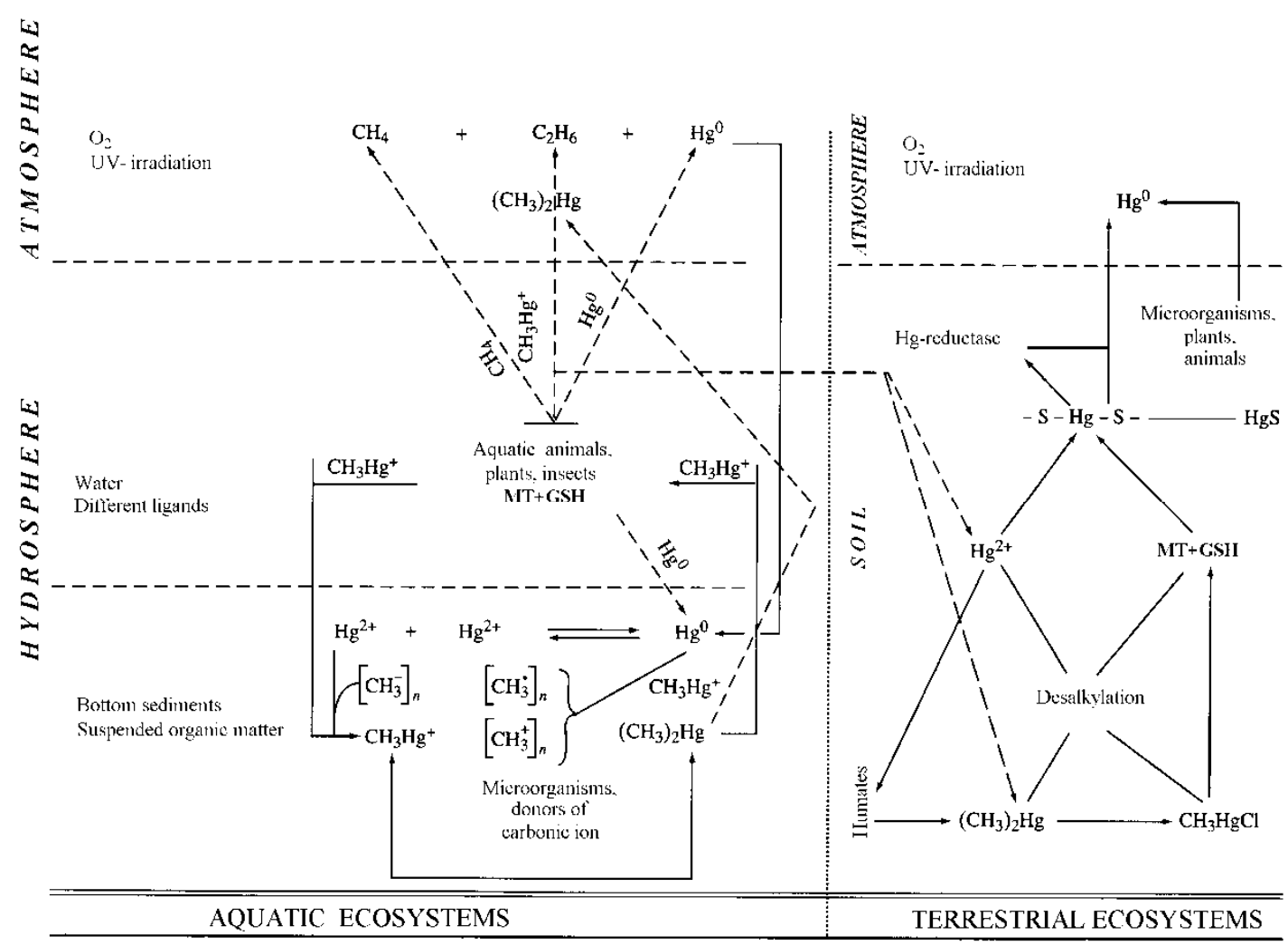

Fig. 6. Transformation of mercury and methyl-mercury in the biosphere. MT - etallothioneines, $\mathrm{GSH}$ - reduction glutathione and its derivatives (phytochelatines). 
Table 1. Conditional stability constants for mercury fulvic complexes of the composition $\mathrm{Hg}: \mathrm{FA}=1: 1$.

\begin{tabular}{cccc}
\hline System & $\mathrm{pH}$ & Mean $\beta_{11}$ & $\lg \beta_{11}$ \\
\hline \multirow{2}{*}{$\mathrm{Hg}^{0}-\mathrm{FA}$} & 5,0 & $3.60 \times 10^{7}$ & 7.56 \\
\cline { 2 - 4 } & 6,0 & $1.03 \times 10^{10}$ & 10.01 \\
\cline { 2 - 4 } & 7,0 & $2.32 \times 10^{11}$ & 11,37 \\
\hline $\mathrm{Hg}^{0}-\mathrm{FA}$ & 5,0 & $7.52 \times 10^{7}$ & 7.88 \\
& 7,0 & $2.99 \times 10^{12}$ & 12.48 \\
\hline
\end{tabular}

Table 2. The experimental $\mathrm{K}_{\mathrm{d}}$ values for mercury at $\mathrm{pH}=5.0$ and 3.0.

\begin{tabular}{ccc}
\hline \multirow{2}{*}{ Model system } & \multicolumn{2}{c}{$\mathrm{Kd}$} \\
\cline { 2 - 3 } & $\mathrm{pH}=5.0$ & $\mathrm{pH}=3.0$ \\
\hline Fulvates mercury - HA & $2 \times 10^{1}$ & $1.5 \times 10^{3}$ \\
\hline FA - Hg(II) - HA & $1.5 \times 10^{2}$ & $4 \times 10^{3}$ \\
\hline Humat Hg- FA & $4 \times 10^{4}$ & $1 \times 10^{4}$ \\
\hline
\end{tabular}

PERIÓDICO TCHÊ QUÍMICA•www.periodico.tchequimica.com• Vol. 16 N. 31.

• ISSN 1806-0374 (impresso) • ISSN 1806-9827 (CD-ROM) • ISSN 2179-0302 (meio eletrônico) (C) 2019. Porto Alegre, RS. Brasil

The Periódico Tchê Química (ISSN: 1806-0374; 2179-0302) is an open-access journal since 2004. Journal DOI: 10.52571/PTQ. http://www.tchequimica.com. This text was introduced in this file in 2021 for compliance reasons.

O The Author(s)
OPEN ACCESS. This article is licensed under a Creative Commons Attribution 4.0 (CC BY 4.0) International License, which permits use, sharing, adaptation, distribution, and reproduction in any medium or format, as long as you give appropriate credit to the original author(s) and the source, provide a link to the Creative Commons license, and indicate if changes were made. The images or other third-party material in this article are included in the article 's Creative Commons license unless indicated otherwise in a credit line to the material . If material is not included in the article's Creative Commons license and your intended use is not permitted by statutory regulation or exceeds the permitted use, you will need to obtain permission directly from the copyright holder. To view a copy of this license, visit http://creativecommons. org/licenses/by/4.0/. 